\title{
Load cell adoption in an electronic drag force flowmeter
}

\author{
Antonio Pires de Camargo; Tarlei Arriel Botrel ${ }^{1 *}$; Ricardo Godoi Vieira ${ }^{2}$; Marinaldo \\ Ferreira Pinto ${ }^{1}$; Lucas Melo Vellame ${ }^{1}$ \\ ${ }^{1}$ USP/ESALQ - Depto. de Engenharia de Biossistemas, C.P. 09 - 13418-900 - Piracicaba, SP - Brasil. \\ ${ }^{2} I T A / I E C$ - Área de Informática, Pça. Marechal Eduardo Gomes, 50 - 12228-900 - São José dos Campos, SP - \\ Brasil. \\ *Corresponding author <tabotrel@esalq.usp.br>
}

\begin{abstract}
This research introduces the development of an electronic flowmeter based on the drag force that a body experiences when immersed in a fluid stream. Its main goal was the development of an Electronic Drag Force Flowmeter (EDFF) using a load cell, as well as the evaluation of its performance parameters. The developed flowmeter should not require specialized labor, equipments, computers or any sophisticated and complex method, providing an easy and accurate way of flow estimation. This research was carried out in the following stages: (i) EDFF mechanical structure development; (ii) data acquisition system and embedded software design; and (iii) evaluation of EDFF performance parameters. EDFF has routines for instantaneous flow rate measurement, interactive calibration, and also several flow meter parameter adjustments, allowing data transmission via a RS232 protocol. The real-time flow measurement task updates values of instantaneous flow rate each seven seconds, enabling unit selection. The interactive calibration routine guides users during all calibration process showing instructions on EDFF's display. A data digital filtering procedure was implemented in an embedded software using the Grubbs' Test in order to identify and to remove outliers from the acquired data. The Method of Least Squares was also implemented in the embedded software in order to calculate the fitting model coefficients on the calibration procedure. This flowmeter is able to work from 1.94 to $7.78 \mathrm{dm}^{3} \mathrm{~s}^{-1}$ with an uncertainty of $\pm 5.7 \%$. The coefficient of local head loss $(\mathrm{K})$ was close to 0.55 for Reynolds number values higher than $10^{5}$. The developed EDFF is a low-cost and stand-alone system with potential for agricultural applications.

Key words: technology innovation, flow measurement, electronics on agriculture
\end{abstract}

\section{Medidor de vazão eletrônico com célula de carga}

\begin{abstract}
RESUMO: Este estudo apresenta o desenvolvimento de um medidor de vazão baseado na força de arraste que atua em um corpo imerso em uma corrente líquida. O principal objetivo foi o desenvolvimento de um Medidor de Vazão Eletrônico tipo Força (MVEF) utilizando célula de carga, bem como a avaliação do desempenho do equipamento. Esta pesquisa foi executada nas seguintes etapas: (i) desenvolvimento da estrutura mecânica do MVEF; (ii) desenvolvimento do sistema de aquisição de dados e do software embarcado; e (iii) avaliação dos parâmetros de desempenho do MVEF. O medidor de vazão desenvolvido possibilita a transmissão de dados via serial (RS-232) e possui rotinas para medição de vazão instantânea, calibração interativa e opções para ajuste de alguns parâmetros de funcionamento. O Teste de Grubbs foi utilizado no software embarcado com a finalidade de identificar e remover dados inconsistentes do conjunto amostral, sendo, portanto, um procedimento de filtragem digital de dados. A rotina de calibração do medidor de vazão consta de um algoritmo que utiliza o Método dos Mínimos Quadrados para determinação dos coeficientes de ajuste do modelo adotado. O medidor de vazão desenvolvido opera na faixa de 1,94 a $7,78 \mathrm{dm}^{3} \mathrm{~s}^{-1}$ com incerteza de $\pm 5,7 \%$. O coeficiente de perda de carga localizada característico do medidor de vazão foi de aproximadamente 0,55 para condições com Número de Reynolds superior a $10^{5}$. O medidor de vazão desenvolvido apresenta baixo custo, sendo viável para utilização em aplicações agrícolas.

Palavras-chave: inovação tecnológica, hidrometria, eletrônica na agricultura
\end{abstract}

\section{Introduction}

The initial spurs to flow measurement were agricultural requirements and necessity to evaluate water consumptions by the users in Egyptian, Roman and Chinese civilizations (Upp and La Nasa, 2002). From the 20th century onwards several new concepts of flowmeters were developed using electronic devices. The impact of new materials, processes, electronics and microprocessors allows a widespread commercial development of modern flowmeter technology (Cascetta, 1995).
Target or drag force flowmeters measure flow by sensing the drag force exerted on a target that intercepts partially the flow stream. The obstruction in the flow path accelerates the fluid and it reduces the pressure on the rear surface of the target. The difference resulted between the upstream and downstream surface pressures, integrated over the target area, is a force (Zhao et al., 2005). The square root of this force is proportional to the flow rate (Delmée, 2002). The force is often sensed by measuring the strain on a beam that supports the target. Flowmeters based on the drag force that a body experi- 
ences when immersed in a fluid stream are hardly found or ment ioned in literature (Merzkirch, 2005). This kind of flowmeters can be used in a wide variety of applications as follows: general liquid or gas application, hot liquids, steam, slurries and particle flows, liquid and gas mixtures (Furness, 1991). In addition, target flowmeters appear to be suitable for use in food industry dealing with fluid products since these meters are easy to be cleaned and sanitized (Greene, 1993).

This research had as main objective the development of an Electronic Drag Force Flowmeter (EDFF) as well as the evealuation of its performance parameters. The developed flowmeter should not require specialized labor, equipment, computers or any sophisticated and complex method, providing an easy and accurate way of measuring flow. Moreover, the EDFF emerged according to innovative ideas becoming a new and low-cost option available to flow measurement in closed conduits.

\section{Material and Methods}

Drag forces $\left(\mathrm{F}_{\mathrm{d}}\right)$ act on bodies immersed in incompressible fluid streams and they can be calculated by eq. (1) depending on a drag coefficient $\left(C_{D}\right)$, characteristic area of the body $(A)$, density of fluid $(\rho)$, and flow velocity $(u)$.

$$
F_{D}=C_{D} \frac{\rho u^{2}}{2} A
$$

The frontal or projected area A that intercepts perpendicularly the flow is a constant. The density of fluid is a function of both the pressure and the temperature. The water density depends on its temperature and can also be considered as a constant since the temperature does not change during a measurement process. For turbulent conditions, the flow velocity in closed conduits varies according to radius $(r)$. The average flow velocity $(V)$ is generally detected at a distance between 0.7 and $0.8 r$ from the center position of a closed conduit (Neves, 1974). Aspects related to swirls and velocity profiles with distorted shapes are not taken into account once it is not the main purpose of this research. In an incompressible flow and in situations in which the body is completely immersed in the fluid, the drag coefficient $\left(C_{D}\right)$ depends mainly on the Reynolds number $(R e)$ and shape of the body. For these situations $R e$ is determined by eq. (2), based on flow velocity $(u)$, kinematic viscosity $(v)$, and the characteristic dimension of the body (l) (Munson et al., 2004).

$\operatorname{Re}=\frac{u l}{v}$

In this research the force caused by the fluid flow acts on a target disc whose surface is oriented perpendicular to the flow direction. The target was attached to the inferior extremity of a cylindrical metal beam. The drag causes a lower pressure area at the rear surface of the target, producing a net force that is transferred to the beam. A load cell was attached to upper extremity of the beam. Strain gauges measure the deflection of the load cell due to drag force acting on target and on the immersed part of the cylindrical beam (Figure 1). The force acting on the target is measured directly instead of measuring the differential pressure, which produces a force on the target, proportional to the square of the flow rate. It was also mentioned by Baker (2000), that target flowmeters for $R e$ values higher than 4000 have a drag force proportional to the square of the velocity. Therefore, analyzing in the simplest way, the flow rate $(Q)$ measured by target flowmeters may be estimated by eq. (3), in which $k$ is assumed as a constant coefficient. A similar equation was mentioned by Delmée (2003) using the differential pressure instead of the drag force.

$Q=k \sqrt{F_{D}}$

The EDFF design, manufacturing, and evaluation were accomplished in the following stages: EDFF mechanical structure development; hardware and embedded software design; and evaluation of EDFF performance parameters.

The EDFF mechanical structure was completely designed using Computer Aided Design (CAD) environment tool in order to reduce mechanical faults. With this tool was possible to reduce time and waste of resources. Figure 2 presents the functional model developed by the CAD tool.

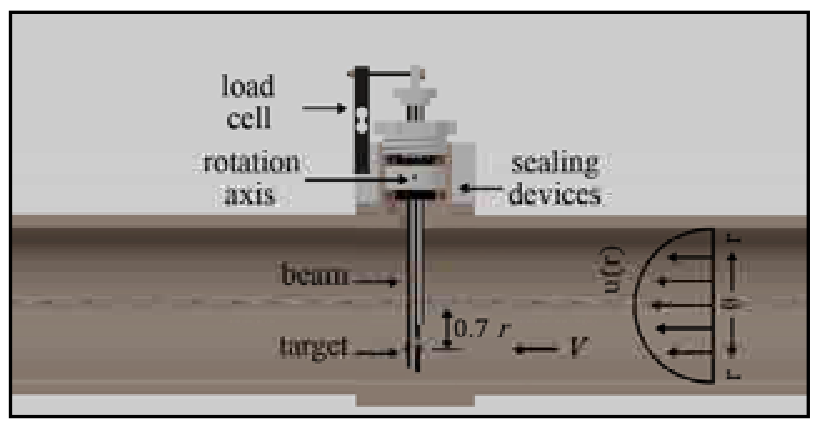

Figure 1 - Fundamental structure of the Electronic Drag Force Flowmeter and the velocity profile schematic for turbulent flow conditions.

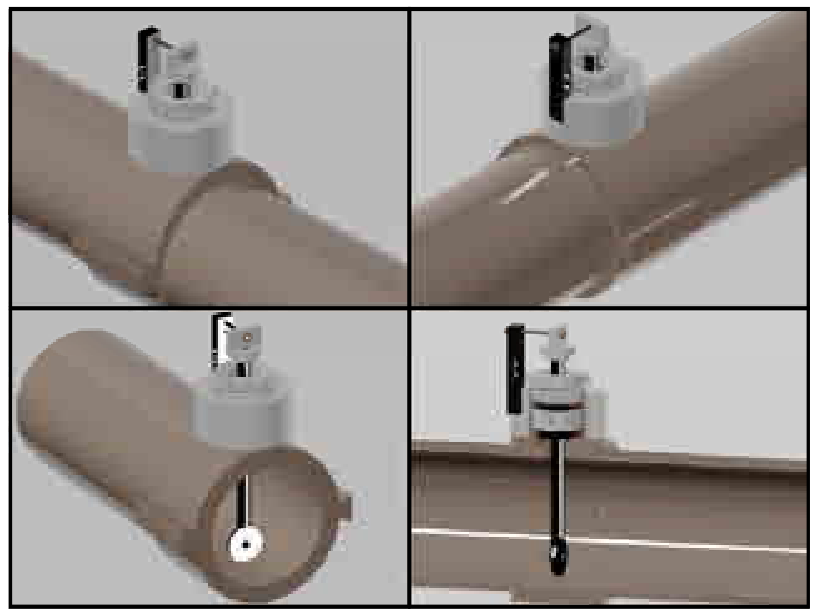

Figure 2 - Electronic Drag Force Flowmeter mechanical structure designed in Computer Aided Design tool. 
A target disc of $20 \mathrm{~mm}$ diameter and $1 \mathrm{~mm}$ thickness was attached to a steel cylindrical beam of $118 \mathrm{~mm}$ length and $7 \mathrm{~mm}$ diameter. These objects were assembled inside a 66 $\mathrm{mm}$ diameter pipeline. The center of the target disc was positioned $0.7 r$ from the center of the pipe transversal section in order to ensure the average velocity acting on the target. A $46.1 \mathrm{~mm}$-long portion of the beam was also immersed. The beam was drilled $72 \mathrm{~mm}$ above the center of target to insert a metal stick of $2 \mathrm{~mm}$ thickness. It provided a rotation axis for the transference of the force from target to a load cell. A bending beam load cell was used with $4.9 \mathrm{~N}$ capacity, sensitivity of $0.002 \mathrm{v} \mathrm{v}^{-1}$ and accuracy of $\pm 0.1 \%$. The sealing mechanism comprises rubber seal rings, metal washers and some PVC fittings. Other PVC and metal fittings were manufactured and used to develop the EDFF mechanical structure (Figure 1 and 2). Figure 3 shows the EDFF developed in this research installed on a pipeline.

An electromagnetic flowmeter (uncertainty of $\pm 0.5 \%$ ) was used as the reference meter in calibration procedures. The EDFF and the electromagnetic flowmeter were installed in a pipeline of $66 \mathrm{~mm}$ diameter. A gate valve was also installed $1 \mathrm{~m}$ downstream of the electromagnetic flowmeter in order to control the flow rate. Figure 4 presents a schematic diagram of experimental setup. The evaluation tests were performed under a constant pressure condition of $98.1 \mathrm{kPa}$. The water temperature during tests remained close to $293 \mathrm{~K}$.

The flowmeter Data Acquisition System (DAS) was developed in order to acquire and process the output signal from the load cell converting it into flow rate. The DAS provides routines for instantaneous flow rate measurement, interactive calibration, and also several flowmeter measuring parameters adjustment. During all development there was a great concern regarding the routine creation in order

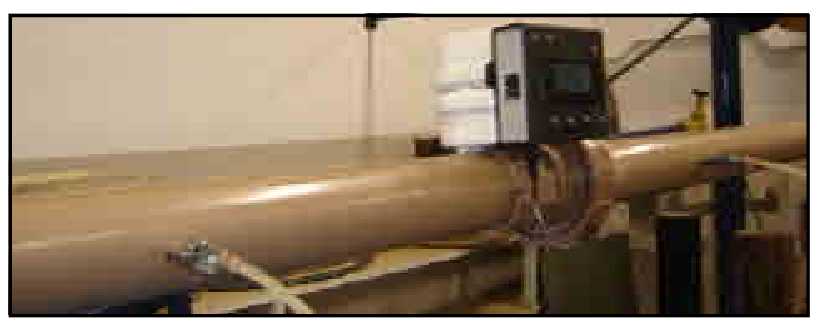

Figure 3 - Electronic Drag Force Flowmeter developed in this research installed on a pipeline.

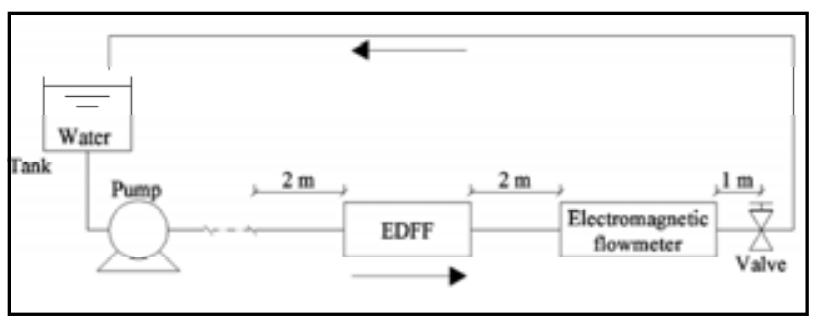

Figure 4 - Schematic diagram of experimental setup. EDFF $=$ Electronic Drag Force Flowmeter. to ensure an easy way to work with the EDFF. The hardware of the DAS is comprised by the following devices: instrumentation amplifier, microcontroller, serial converter device, liquid-crystal display (LCD), capacitors, resistors, voltage regulators, control buttons, and power supply of 15 Vcc.

After assemblage of these items, the DAS hardware is able to: (i) provide a precision voltage reference of 10 Vcc for load cell supply; (ii) amplify the load cell output signals; (iii) convert the amplified output signals into digital data using the internal $\mathrm{A} / \mathrm{D}$ converter of the microcontroller with 10 bits of resolution; (iv) perform digital data processing using a PIC18F4550 microcontroller; (v) display instructions and information on a LCD; (vi) access routines using control buttons; and (vii) allow sending the acquired data to a microcomputer.

The embedded software in the DAS provides the following tasks: (i) access a real-time flow measurement that updates values of instantaneous flow rate each seven seconds, enabling unit selection $\left(\mathrm{m}^{3} \mathrm{~s}^{-1}, \mathrm{~m}^{3} \mathrm{~h}^{-1}, \mathrm{~L} \mathrm{~s}^{-1}\right.$, and $\left.\mathrm{L} \mathrm{h}^{-1}\right)$; (ii) access an interactive calibration guiding user along all calibration process; (iii) perform several flowmeter parameter adjustments; and (iv) allow the acquired data transmission via RS-232 protocol to a microcomputer (Figure 5).

A data digital filtering procedure was implemented in the embedded software using the Grubbs' Test, in order to identify outliers and remove them from the acquired data (ISO $5168,1985)$. This procedure was used for instantaneous flow rate measurement and for interactive calibration routines. In this research, data is designated as "raw data" before digital filtering, while data is designated as "processed data" after digital filtering.

The interactive calibration task guides the user along the calibration procedure. The flowmeter LCD displays sequential instructions to the user. Along this procedure the flow rate data is gathered from 0.00 to $8.33 \mathrm{dm}^{3} \mathrm{~s}^{-1}$. The acquired data necessary to calculate the fitting model coefficients is stored in a microcontroller (RAM memory). The obtained coefficients for each calibration task are stored in the microcontroller memory allowing changes when necessary (EEPROM memory).

The Method of Least Squares was implemented in the embedded software in order to calculate the fitting model coefficients. A logarithmic model was used to predict the flow rate (eq. 4$)$, and regression coefficients $(A$ and $B$ ) were determined by eq. 5 . The determination coefficient $\left(r^{2}\right)$ was calculated by eq. 6 (Souza, 2009).

$Q=A+B \ln (x)$

$$
\left\{\begin{array}{l}
30 A+\left[\sum_{i=1}^{30} \ln \left(x_{i}\right)\right] B=\sum_{i=1}^{30} Q_{i} \\
{\left[\sum_{i=1}^{30} \ln \left(x_{i}\right)\right] A+\left\{\sum_{i=1}^{30}\left[\ln \left(x_{i}\right)\right]^{2}\right\} B=\sum_{i=1}^{30}\left[Q_{i} \ln \left(x_{i}\right)\right]}
\end{array}\right.
$$




$$
r^{2}=1-\frac{\sum_{i=1}^{30}\left[Q_{i}-A-B \cdot \ln \left(x_{i}\right)\right]^{2}}{\left[\sum_{i=1}^{30}\left(Q_{i}^{2}\right)\right]-\left[\frac{1}{30} \cdot\left(\sum_{i=1}^{30} Q_{i}\right)^{2}\right]}
$$

where: $A$ and $B$ are Regression coefficients; $x_{i}: i^{\text {th }}$ processed data; $Q_{i:} i^{\text {th }}$ value of reference flow rate.

Taking into account the DAS features it is reasonable to consider EDFF as a stand-alone system. All the mathematical processes are performed by the microcontroller. The system allows data transmission from the microcontroller to an external microcomputer via a serial port (RS-232). The data transmission to a microcomputer may be useful to create reports, charts, and also allows performing other complex routines. One of the DAS challenges was to define the sample size $(n)$. Three replicates of two sample sizes were evaluated $(n=30$ and $n=500)$. These tests were performed on three different flow conditions $\left(0.0,4.17\right.$, and $\left.6.25 \mathrm{dm}^{3} \mathrm{~s}^{-1}\right)$. A sampling interval of 250 milliseconds was used.

Statistical and performance parameters like repeatability, hysteresis, conformity, and uncertainty interval limits, as well as curve model fitting were determined based on four tests. Data was gathered by increasing and decreasing flow rates, changing values on intervals of $0.28 \mathrm{dm}^{3}$ $\mathrm{s}^{-1}$ in a range from 0.0 to $8.33 \mathrm{dm}^{3} \mathrm{~s}^{-1}$. The flow rate was controlled using a gate valve and observing flow rates in an electromagnetic flowmeter installed in series downstream from EDFF (Figure 4). The determination of the EDFF uncertainty limit $(U)$ was performed adopting procedures presented by ISO 5168 (1985). The equation used to combine bias errors $(B)$ and random errors $(S)$ is presented below:

$U=\sqrt{B^{2}+(2 S)^{2}}$

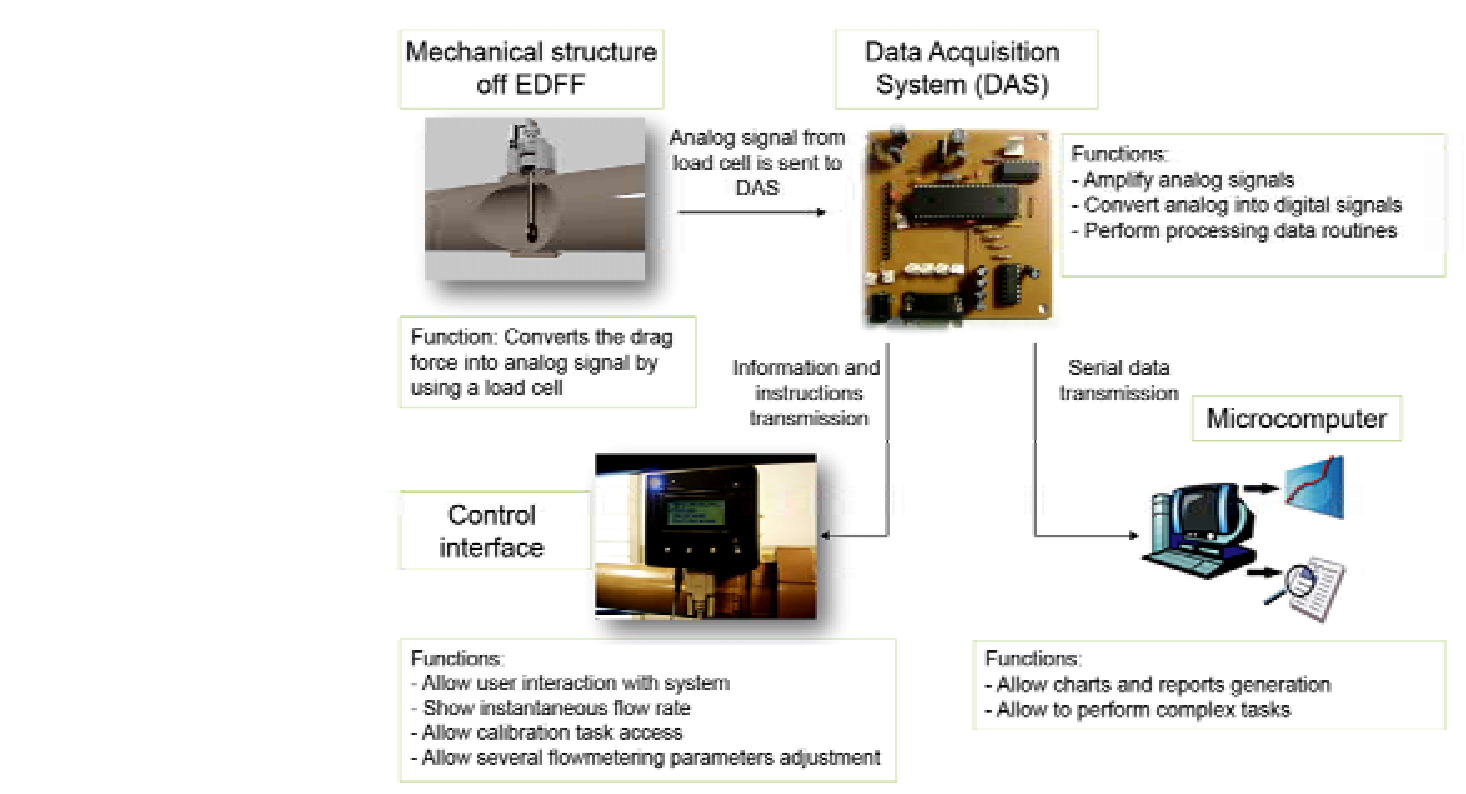

Local head losses are originated due to sudden changes in flow condition caused by pipe fittings or other flow interferences increasing flow turbulence and energy loss (Porto, 1998). The local head loss coefficient $(K)$ of the EDFF was determined experimentally. The head loss was calculated based on eqs 8 and 9. A differential manometer was installed distanced of $0.4 \mathrm{~m}$ upstream and downstream from the EDFF. A manometric fluid of density (d) $1750 \mathrm{~kg} \mathrm{~m}^{-3}$ (Figure 6) was used.

$h f_{l o c}=K \frac{V^{2}}{2 g}$

$h f_{\text {loc }}=0.75 \Delta h$

where: $h f_{\text {loc }}$ local head loss $(\mathrm{m}) ; K$ coefficient of local head loss ( - ); $V$ average flow velocity $\left(\mathrm{m} \mathrm{s}^{-1}\right) ; g$ : acceleration of gravity $=9.81 \mathrm{~m} \mathrm{~s}^{-2} ; \Delta b$ : differential pressure between 1 and $2(\mathrm{~m})$.

\section{Results and Discussion}

Sample size determination is an important and hard stage on planning any gathering data or sampling process (Dattalo, 2008). As larger the sample size is, the smaller the expected random error will be (Cacuci, 2003; Drosg, 2007). Any controller has limited storage and processing capacity due to price and physical space. Large sample sizes require more processing time to update and display data for users. Hence, sample size is a constraint aspect for an electronic flowmeter development. Grubbs' Test is a recommended mathematical procedure for data processing in flow measurement systems (ISO 5168, 1985). Applying this procedure to a set of data with 500 values $(n=500)$, considering three different flow rates $\left(0.00,4.17\right.$, and $\left.6.25 \mathrm{dm}^{3} \mathrm{~s}^{-1}\right)$, and three replicates we obtained the results shown in Table 1.

Figure 5 - Schematic diagram of the Electronic Drag Force Flowmeter features. 
During tests with flow rate of $0.00 \mathrm{dm}^{3} \mathrm{~s}^{-1}$, we detected and eliminated 15 outliers from replicate 1 (R1), 17 outliers from replicate 2 (R2) and 18 outliers from replicate 3 (R3). The resulted average of the final data under this flow condition was 82.2 bytes. By setting flow rate to $4.17 \mathrm{dm}^{3}$ $\mathrm{s}^{-1}$ we found 2 outliers in $\mathrm{R} 3$ resulting an average of pro-

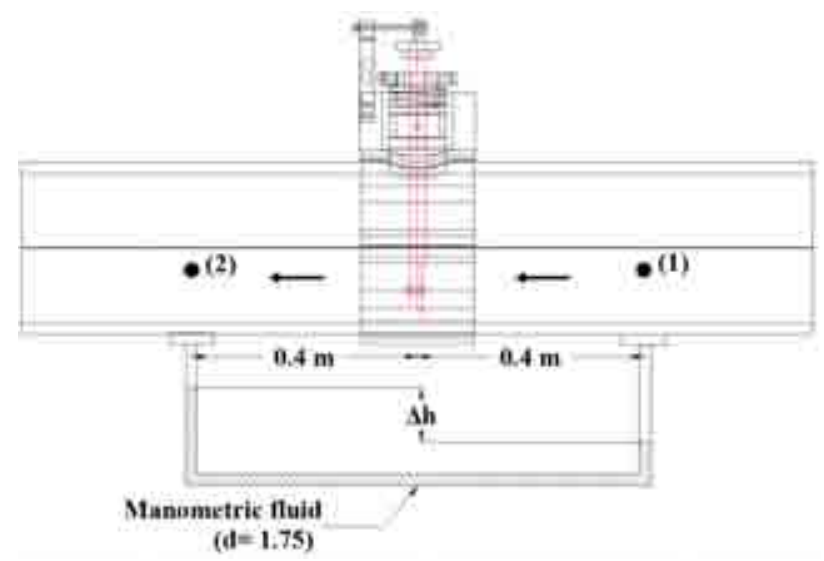

Figure 6 - Differential manometer and pressure taps arrangement. cessed data of 314.8 bytes. Processed data for the $6.25 \mathrm{dm}^{3}$ $\mathrm{s}^{-1}$ flow condition we found two outliers in R2, resulting an average of 635.3 bytes. The same tests were performed with sample size $30(n=30)$ applying the Grubb's Test procedure, as shown in Table 2 . We found three outliers in R2 for the $0.00 \mathrm{dm}^{3} \mathrm{~s}^{-1}$ flow condition. The small number of detected outliners was expected once measurement systems generally acquire a little number of data and the probability of outlier occurrence is small (Rabinovich, 2005). Differences in the processed data were very small between sample sizes of 500 and 30 (Tables 1 and 2). Therefore, it is reasonable to consider that it is not necessary to process more than 30 values in each sampling cycle. Using $n=30$ the required time to gather, process, and update data was close to seven seconds.

Table 3 presents the results from four tests carried out in order to determine the statistical performance of parameters as repeatability, hysteresis, conformity, and uncertainty interval limits. The used model fitting to estimate flow rates was also mentioned in this item. The maximum repeatability error value was 19.6 bytes respectively to $7.78 \mathrm{dm}^{3}$ $\mathrm{s}^{-1}$ (Table 4$)$. The repeatability error was $\pm 1.9 \%$ based on a full scale (FS). Since an A/D converter with 10 bits of reso-

Table 1 - Summarized results obtained to sample size of 500 values $(n=500)$.

\begin{tabular}{|c|c|c|c|c|c|c|c|}
\hline \multirow{2}{*}{ Flow rate } & \multirow{2}{*}{$n$} & \multirow{2}{*}{ Rep. } & \multicolumn{2}{|c|}{ Raw data } & \multicolumn{2}{|c|}{ Processed data } & \multirow{2}{*}{$\begin{array}{c}\text { Number of } \\
\text { outliers }\end{array}$} \\
\hline & & & Average & C.V. & Average & C.V. & \\
\hline $\mathrm{dm}^{3} \mathrm{~s}^{-1}$ & & & by tes & $\%$ & bytes & $\%$ & \\
\hline 0.00 & 500 & $\mathrm{R} 1$ & 82.6 & 3.0 & 82.5 & 1.8 & 15 \\
\hline 0.00 & 500 & $\mathrm{R} 2$ & 82.7 & 3.4 & 82.4 & 1.8 & 17 \\
\hline 0.00 & 500 & R3 & 81.8 & 4.4 & 81.8 & 1.5 & 18 \\
\hline 4.17 & 500 & R1 & 312.0 & 4.2 & 312.0 & 4.2 & 0 \\
\hline 4.17 & 500 & $\mathrm{R} 2$ & 313.4 & 4.3 & 313.4 & 4.3 & 0 \\
\hline 4.17 & 500 & R3 & 317.9 & 7.2 & 319.0 & 4.4 & 2 \\
\hline 6.25 & 500 & R1 & 636.9 & 2.7 & 636.9 & 2.7 & 0 \\
\hline 6.25 & 500 & $\mathrm{R} 2$ & 633.7 & 5.6 & 635.7 & 2.7 & 2 \\
\hline 6.25 & 500 & $\mathrm{R} 3$ & 633.2 & 2.6 & 633.2 & 2.6 & 0 \\
\hline
\end{tabular}

Table 2 - Summarized results obtained to sample size of 30 values $(n=30)$.

\begin{tabular}{|c|c|c|c|c|c|c|c|}
\hline \multirow{2}{*}{ Flow rate } & \multirow{2}{*}{$n$} & \multirow{2}{*}{ Rep. } & \multicolumn{2}{|c|}{ Raw data } & \multicolumn{2}{|c|}{ Processed data } & \multirow{2}{*}{$\begin{array}{c}\text { Number of } \\
\text { outliers }\end{array}$} \\
\hline & & & Average & C.V. & Average & C.V. & \\
\hline $\mathrm{dm}^{3} \mathrm{~s}^{-1}$ & & & bytes & $\%$ & bytes & $\%$ & \\
\hline 0.00 & 30 & $\mathrm{R} 1$ & 81.2 & 1.8 & 81.2 & 1.8 & 0 \\
\hline 0.00 & 30 & $\mathrm{R} 2$ & 83.6 & 4.2 & 83.1 & 1.7 & 3 \\
\hline 0.00 & 30 & R3 & 81.8 & 1.5 & 81.8 & 1.5 & 0 \\
\hline 4.17 & 30 & $\mathrm{R} 1$ & 309.8 & 3.5 & 309.8 & 3.5 & 0 \\
\hline 4.17 & 30 & $\mathrm{R} 2$ & 309.2 & 5.3 & 309.2 & 5.3 & 0 \\
\hline 4.17 & 30 & R3 & 316.8 & 3.5 & 316.8 & 3.5 & 0 \\
\hline 6.25 & 30 & $\mathrm{R} 1$ & 636.8 & 2.9 & 636.8 & 2.9 & 0 \\
\hline 6.25 & 30 & $\mathrm{R} 2$ & 638.5 & 3.1 & 638.5 & 3.1 & 0 \\
\hline 6.25 & 30 & R3 & 631.1 & 2.9 & 631.1 & 2.9 & 0 \\
\hline
\end{tabular}

Sci. Agric. (Piracicaba, Braz.), v.68, n.3, p.275-284, May/June 2011 
Table 3 - Data gathered in order to estimate the Electronic Drag Force Flowmeter performance parameters.

\begin{tabular}{|c|c|c|c|c|c|c|c|c|}
\hline \multirow{3}{*}{$\begin{array}{l}\text { Flow rate } \\
\left(\mathrm{dm}^{3} \mathrm{~s}^{-1}\right)\end{array}$} & \multicolumn{8}{|c|}{ Processed data (by tes) } \\
\hline & \multicolumn{2}{|c|}{ Test 1} & \multicolumn{2}{|c|}{ Test 2} & \multicolumn{2}{|c|}{ Test 3} & \multicolumn{2}{|c|}{ Test 4} \\
\hline & $\mathrm{I}$ & $\mathrm{D}$ & $\mathrm{I}$ & $\mathrm{D}$ & $\mathrm{I}$ & $\mathrm{D}$ & $\mathrm{I}$ & $\mathrm{D}$ \\
\hline 0.00 & 81.3 & 88.8 & 82.7 & 90.2 & 85.4 & 90.7 & 79.8 & 88.4 \\
\hline 0.28 & 79.9 & 88.5 & 85.1 & 93.1 & 87.6 & 89.7 & 86.0 & 85.7 \\
\hline 0.56 & 86.0 & 94.7 & 81.2 & 97.8 & 86.9 & 93.3 & 86.2 & 90.6 \\
\hline 0.83 & 88.5 & 95.8 & 89.0 & 101.5 & 92.4 & 98.1 & 96.7 & 91.2 \\
\hline 1.11 & 92.5 & 107.0 & 91.3 & 108.8 & 98.9 & 103.7 & 100.1 & 101.4 \\
\hline 1.39 & 101.6 & 111.9 & 102.5 & 114.4 & 108.3 & 113.3 & 108.1 & 111.9 \\
\hline 1.67 & 112.1 & 122.4 & 110.7 & 121.8 & 111.9 & 123.5 & 119.5 & 122.5 \\
\hline 1.94 & 122.7 & 138.8 & 122.5 & 140.1 & 132.6 & 136.9 & 129.1 & 138.3 \\
\hline 2.22 & 139.4 & 150.3 & 134.0 & 154.0 & 142.7 & 158.3 & 141.6 & 150.9 \\
\hline 2.50 & 152.5 & 165.9 & 150.5 & 171.4 & 158.5 & 171.0 & 152.0 & 166.6 \\
\hline 2.78 & 176.6 & 184.6 & 173.4 & 193.0 & 176.5 & 192.1 & 174.3 & 187.6 \\
\hline 3.06 & 199.3 & 207.0 & 195.9 & 218.2 & 199.2 & 211.7 & 206.0 & 211.2 \\
\hline 3.33 & 227.7 & 235.0 & 225.9 & 244.1 & 233.3 & 230.4 & 228.5 & 237.6 \\
\hline 3.61 & 252.7 & 256.8 & 256.0 & 262.3 & 245.4 & 262.5 & 252.5 & 259.8 \\
\hline 3.89 & 281.9 & 283.8 & 283.5 & 293.1 & 278.1 & 282.7 & 279.4 & 284.3 \\
\hline 4.17 & 321.1 & 315.9 & 318.9 & 321.5 & 312.2 & 316.0 & 308.0 & 315.6 \\
\hline 4.44 & 356.6 & 353.6 & 355.1 & 345.9 & 349.5 & 356.9 & 346.3 & 344.9 \\
\hline 4.72 & 391.5 & 399.6 & 378.2 & 394.0 & 382.5 & 389.4 & 379.3 & 391.1 \\
\hline 5.00 & 428.5 & 425.6 & 434.4 & 427.7 & 418.3 & 437.9 & 429.8 & 417.8 \\
\hline 5.28 & 467.5 & 470.2 & 465.2 & 465.1 & 470.7 & 467.7 & 465.9 & 456.8 \\
\hline 5.56 & 508.3 & 508.7 & 517.7 & 516.5 & 511.8 & 520.0 & 510.0 & 515.0 \\
\hline 5.83 & 565.4 & 551.6 & 568.8 & 555.9 & 560.1 & 57.2 & 561.3 & 554.8 \\
\hline 6.11 & 601.4 & 608.1 & 608.3 & 608.7 & 610.5 & 597.6 & 603.6 & 604.6 \\
\hline 6.39 & 662.4 & 657.6 & 671.9 & 653.3 & 657.2 & 655.2 & 659.7 & 655.5 \\
\hline 6.67 & 700.5 & 700.3 & 712.9 & 706.1 & 699.4 & 711.1 & 718.2 & 714.0 \\
\hline 6.94 & 757.5 & 762.2 & 764.8 & 755.6 & 765.7 & 769.1 & 775.7 & 755.6 \\
\hline 7.22 & 823.0 & 811.1 & 822.2 & 814.3 & 816.9 & 804.9 & 804.2 & 808.9 \\
\hline 7.50 & 879.3 & 875.8 & 881.6 & 865.2 & 885.5 & 868.2 & 871.6 & 881.3 \\
\hline 7.78 & 924.8 & 931.2 & 931.7 & 939.5 & 944.4 & 941.8 & 934.9 & 937.2 \\
\hline 8.06 & 985.9 & 989.6 & 998.3 & 992.6 & 980.7 & 994.4 & 996.0 & 988.7 \\
\hline 8.33 & 1022.7 & 1011.8 & 1023.0 & 1022.6 & 1022.9 & 1023.0 & 1023.0 & 1023.0 \\
\hline
\end{tabular}

I - Processed data from increasing flow condition; D - Processed data from decreasing flow condition.

lution was used, the value of FS is reached for 1024 bytes. To estimate the hysteresis error tests of increasing and decreasing flow rate values were carried out (Table 4). The largest difference obtained between increasing and decreasing flow rates was 15.4 bytes respectively to $2.50 \mathrm{dm}^{3} \mathrm{~s}^{-1}$. Therefore, the hysteresis error was estimated to be $\pm 1.5 \%$ based on FS.

As mentioned for eq. (3), $Q$ measured by target flowmeters may be estimated as a function of $F_{D}$ and the constant $k$. The load cell installed in the developed EDFF has a linear output signal. The force that acts on load cell $\left(F_{L C}\right)$ is not exactly equal to the drag force since there is a distance above the fulcrum (rotation axis) of $46 \mathrm{~mm}\left(L_{1}\right)$ and below the fulcrum of $72 \mathrm{~mm}\left(L_{2}\right)$. Then, $F_{D}$ can also be expressed by eq. (10), where $x$ is processed data, $k_{1}$ and $k_{2}$ are constant values determined by load cell characteristic:

$F_{D}=\left(k_{1} x+k_{2}\right) \frac{L_{1}}{L_{2}}$

Analyzing eq. (3) and eq. (10):

$Q=k \sqrt{\left(k_{1} x+k_{2}\right) \frac{L_{1}}{L_{2}}}$ 
Table 4 - Values used on analysis of repeatability and hysteresis errors.

\begin{tabular}{|c|c|c|c|c|}
\hline Flow rate & Average of I condition & Average of $\mathrm{D}$ condition & Difference between I and D & Repeatability error \\
\hline \multicolumn{5}{|c|}{ - by tes $\ldots$} \\
\hline 0.00 & 82.3 & 89.5 & -7.2 & 5.6 \\
\hline 0.28 & 84.7 & 89.3 & -4.6 & 7.7 \\
\hline 0.56 & 85.1 & 94.1 & -9.0 & 5.7 \\
\hline 0.83 & 91.7 & 96.7 & -5.0 & 8.2 \\
\hline 1.11 & 95.7 & 105.2 & -9.5 & 8.8 \\
\hline 1.39 & 105.1 & 112.9 & -7.8 & 6.7 \\
\hline 1.67 & 113.6 & 122.6 & -9.0 & 8.8 \\
\hline 1.94 & 126.7 & 138.5 & -11.8 & 10.1 \\
\hline 2.22 & 139.4 & 153.4 & -14.0 & 8.7 \\
\hline 2.50 & 153.4 & 168.7 & -15.4 & 8.0 \\
\hline 2.78 & 175.2 & 189.3 & -14.1 & 3.2 \\
\hline 3.06 & 200.1 & 212.0 & -11.9 & 10.1 \\
\hline 3.33 & 228.9 & 236.8 & -7.9 & 7.4 \\
\hline 3.61 & 251.7 & 260.4 & -8.7 & 10.6 \\
\hline 3.89 & 280.7 & 286.0 & -5.3 & 5.4 \\
\hline 4.17 & 315.1 & 317.3 & -2.2 & 13.1 \\
\hline 4.44 & 351.9 & 350.3 & 1.5 & 10.3 \\
\hline 4.72 & 382.9 & 393.5 & -10.7 & 13.3 \\
\hline 5.00 & 427.8 & 427.3 & 0.5 & 16.1 \\
\hline 5.28 & 467.3 & 465.0 & 2.4 & 5.5 \\
\hline 5.56 & 512.0 & 515.1 & -3.1 & 9.4 \\
\hline 5.83 & 563.9 & 554.9 & 9.0 & 8.7 \\
\hline 6.11 & 606.0 & 604.8 & 1.2 & 9.1 \\
\hline 6.39 & 662.8 & 655.4 & 7.4 & 14.7 \\
\hline 6.67 & 707.8 & 707.9 & -0.1 & 18.8 \\
\hline 6.94 & 765.9 & 760.6 & 5.3 & 18.2 \\
\hline 7.22 & 816.6 & 809.8 & 6.8 & 18.8 \\
\hline 7.50 & 879.5 & 872.6 & 6.9 & 13.9 \\
\hline 7.78 & 934.0 & 937.4 & -3.5 & 19.6 \\
\hline 8.06 & 990.2 & 991.3 & -1.1 & 17.6 \\
\hline 8.33 & 1022.9 & 1020.1 & 2.8 & 0.3 \\
\hline
\end{tabular}

I - Processed data from increasing flow condition; D - Processed data from decreasing flow condition.

By grouping some of the constant values, a theoretical model to estimate $Q$ is given by:

$$
Q=k \sqrt{\left(k_{3} x+k_{4}\right)}
$$

The fitting model used to convert processed data (bytes) into flow rate values $\left(\mathrm{dm}^{3} \mathrm{~s}^{-1}\right)$ was determined from average values presented in Table 3 . The theoretical model (eq. 12) was compared with a logarithmic model presented as eq. (4). The choice of the adopted model was based on the coefficient of determination $\left(r^{2}\right)$ (Figure 7 ).

Theoretical model:

$$
\begin{aligned}
Q & =0.3633 \sqrt{0.5405 x-42.9194} \\
r^{2} & =0.938
\end{aligned}
$$

Logarithmic model:

$Q=2.992 \ln (x)-12.89$

$r^{2}=0.993$

Based on $r^{2}$ the logarithmic model was implemented on the embedded software. The coefficient of determination of the theoretical model could be higher than 0.938 , probably due to imperfections in the manufacturing pro- 
cess of the EDFF mechanical structure, which was handmade and it probably was harmflul for the EDFF performance.

When a mathematic model that describes data distribution is non linear, the term conformity is used instead of linearity (Delmée, 2003). Based on the logarithmic model the conformity analysis resulted in a maximum deviation of $\pm 0.50 \mathrm{dm}^{3} \mathrm{~s}^{-1}$ for a reference flow rate of $8.33 \mathrm{dm}^{3} \mathrm{~s}^{-1}$. Hence, the conformity error of range from 0.00 to $8.33 \mathrm{dm}^{3}$ $\mathrm{s}^{-1}$ is $\pm 6.0 \%$. If the measurement range would be restricted to flow rates between 0.28 and $8.06 \mathrm{dm}^{3} \mathrm{~s}^{-1}$ the maximum conformity error would be $0.31 \mathrm{dm}^{3} \mathrm{~s}^{-1}( \pm 3.7 \%)$. In the same way, if the range would be even more limited, from 1.94 to $7.78 \mathrm{dm}^{3} \mathrm{~s}^{-1}$ the respective conformity error would be $\pm 0.22 \mathrm{dm}^{3} \mathrm{~s}^{-1}( \pm 2.7 \%$ ) (Table 5).

According to the procedure of ISO 5168 (1985) the estimated random error limits are equal to $\pm 0.21 \mathrm{dm}^{3}$ $\mathrm{s}^{-1}$. This result was obtained combining random errors of repeatability $\left( \pm 1.9 \%\right.$ or $\pm 0.16 \mathrm{dm}^{3} \mathrm{~s}^{-1}$ ) and hysteresis $\left( \pm 1.5 \%\right.$ or $\left.\pm 0.13 \mathrm{dm}^{3} \mathrm{~s}^{-1}\right)$, on the range 0.00 to $8.33 \mathrm{dm}^{3} \mathrm{~s}^{-1}$. The bias error limits were estimated for three flow measurement ranges. The conformity error was the only evaluated type of bias error. Based on ranges from 0.00 to $8.33 \mathrm{dm}^{3} \mathrm{~s}^{-1}$, from 0.28 to $8.06 \mathrm{dm}^{3} \mathrm{~s}^{-1}$, and from 1.94 to $7.78 \mathrm{dm}^{3} \mathrm{~s}^{-1}$, the respective bias errors were $\pm 6 \%\left( \pm 0.5 \mathrm{dm}^{3} \mathrm{~s}^{-1}\right), \pm 3.7 \%\left( \pm 0.31 \mathrm{dm}^{3} \mathrm{~s}^{-1}\right)$, and $\pm 2.7 \%\left( \pm 0.22 \mathrm{dm}^{3} \mathrm{~s}^{-1}\right)$. By merging bias error limits with random error limits for the three flow measurement ranges, the uncertainty error limits were $\pm 7.8 \%$, $\pm 6.3 \%$, and $\pm 5.7 \%$, respectively.

Otherwise, if the theoretical model would used to express flow rate as a function of the processed data, the EDFF performance parameters would change depending on flowmeter measuring range. The performance results using the theoretical model were obtained following the same procedures already cited for the logarithmic model. The EDFF performance results are summarized in Table 6, presenting results of both logarithmic and theoretical models.

The EDFF works in a range from 1.94 to $7.78 \mathrm{dm}^{3} \mathrm{~s}^{-1}$ with an uncertainty limit of $\pm 5.7 \%$. The EDFF presents a

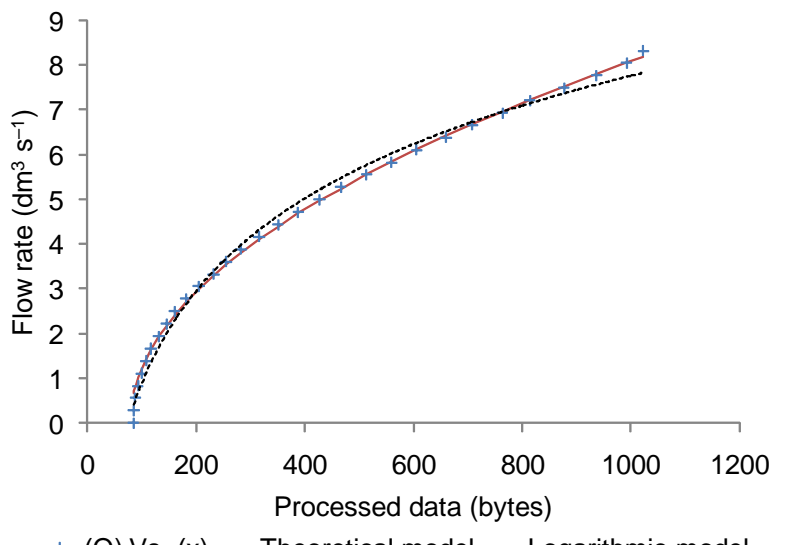

+ (Q) Vs. (x) - Theoretical model --.-- Logarithmic model

Figure 7 - Assessment of the theoretical and logarithmic models. turndown ratio of 4:1. According to Delmée (2003), target flowmeters present uncertainty limits between $0.5 \%$ and $5.0 \%$. Furthermore, these flowmeters are characterized by turndown ratio of 3:1 (Furness, 1991). Baker (2000) mentions that uncertainty of target flowmeters is between $0.5 \%$ and $2.0 \%$ of full scale, whereas the turndown ratio is limited to $4: 1$ or $5: 1$. Just for comparison of values: Venturi flowmeters present uncertainty limits between $0.5 \%$ and $1.5 \%$, and turndown ratio of $3: 1$; Ultrasonic flowmeters based on Doppler Effect have uncertainty limits between $2.0 \%$ and $5.0 \%$, and turndown ratio of 10:1 (Upp and La Nasa, 2002).

Table 5 - Deviation between reference and calculated flow rates using the logarithmic model.

\begin{tabular}{|c|c|c|c|}
\hline $\begin{array}{l}\text { Reference } \\
\text { flow rate }\end{array}$ & $\begin{array}{c}\text { Processed data } \\
\text { Average of } \\
\text { tests }\end{array}$ & $\begin{array}{l}\text { Calculated } \\
\text { flow rate }\end{array}$ & $\begin{array}{l}\text { Deviation between } \\
\text { reference and } \\
\text { calculated flow rate }\end{array}$ \\
\hline $\mathrm{dm}^{3} \mathrm{~s}^{-1}$ & bytes & $\ldots$ & $\mathrm{dm}^{3} \mathrm{~s}^{-1}$ \\
\hline 0.00 & 82.3 & 89.5 & -7.2 \\
\hline 0.28 & 84.7 & 89.3 & -4.6 \\
\hline 0.56 & 85.1 & 94.1 & -9.0 \\
\hline 0.83 & 91.7 & 96.7 & -5.0 \\
\hline 1.11 & 95.7 & 105.2 & -9.5 \\
\hline 1.39 & 105.1 & 112.9 & -7.8 \\
\hline 1.67 & 113.6 & 122.6 & -9.0 \\
\hline 1.94 & 126.7 & 138.5 & -11.8 \\
\hline 2.22 & 139.4 & 153.4 & -14.0 \\
\hline 2.50 & 153.4 & 168.7 & -15.4 \\
\hline 2.78 & 175.2 & 189.3 & -14.1 \\
\hline 3.06 & 200.1 & 212.0 & -11.9 \\
\hline 3.33 & 228.9 & 236.8 & -7.9 \\
\hline 3.61 & 251.7 & 260.4 & -8.7 \\
\hline 3.89 & 280.7 & 286.0 & -5.3 \\
\hline 4.17 & 315.1 & 317.3 & -2.2 \\
\hline 4.44 & 351.9 & 350.3 & 1.5 \\
\hline 4.72 & 382.9 & 393.5 & -10.7 \\
\hline 5.00 & 427.8 & 427.3 & 0.5 \\
\hline 5.28 & 467.3 & 465.0 & 2.4 \\
\hline 5.56 & 512.0 & 515.1 & -3.1 \\
\hline 5.83 & 563.9 & 554.9 & 9.0 \\
\hline 6.11 & 606.0 & 604.8 & 1.2 \\
\hline 6.39 & 662.8 & 655.4 & 7.4 \\
\hline 6.67 & 707.8 & 707.9 & -0.1 \\
\hline 6.94 & 765.9 & 760.6 & 5.3 \\
\hline 7.22 & 816.6 & 809.8 & 6.8 \\
\hline 7.50 & 879.5 & 872.6 & 6.9 \\
\hline 7.78 & 934.0 & 937.4 & -3.5 \\
\hline 8.06 & 990.2 & 991.3 & -1.1 \\
\hline 8.33 & 1022.9 & 1020.1 & 2.8 \\
\hline
\end{tabular}


Table 6 - Summarized Electronic Drag Force Flowmeter (EDFF) performance results.

\begin{tabular}{lcc}
\hline \multirow{2}{*}{ Performance parameter } & \multicolumn{2}{c}{ Maximum error $(\%$ of FS) } \\
\cline { 2 - 3 } Repeatability & Logarithmic model & Theoretical model \\
Hysteresis & \pm 1.9 & \pm 1.9 \\
Conformity error $\left(0.00\right.$ to $\left.8.33 \mathrm{dm}^{3} \mathrm{~s}^{-1}\right)$ & \pm 1.5 & \pm 1.5 \\
Conformity error $\left(0.28\right.$ to $\left.8.06 \mathrm{dm}^{3} \mathrm{~s}^{-1}\right)$ & \pm 6.0 & \pm 8.2 \\
Conformity error $\left(1.94\right.$ to $\left.7.78 \mathrm{dm}^{3} \mathrm{~s}^{-1}\right)$ & \pm 3.7 & \pm 5.4 \\
Uncertainty limit $\left(0.00\right.$ to $\left.8.33 \mathrm{dm}^{3} \mathrm{~s}^{-1}\right)$ & \pm 2.7 & \pm 1.0 \\
Uncertainty limit $\left(0.28\right.$ to $\left.8.06 \mathrm{dm}^{3} \mathrm{~s}^{-1}\right)$ & \pm 6.3 & \pm 9.6 \\
Uncertainty limit $\left(1.94\right.$ to $\left.7.78 \mathrm{dm}^{3} \mathrm{~s}^{-1}\right)$ & \pm 5.7 & \pm 7.4 \\
\hline
\end{tabular}

If the theoretical model would be adopted the uncertainty limit would be $\pm 5.1 \%$, considering the flowmeter measuring range from 1.94 to $7.78 \mathrm{dm}^{3} \mathrm{~s}^{-1}$. However, for flow rate values beyond the mentioned range, the accuracy of the measurement process would be worse than for the adopted logarithmic model. In the laminar regime the target flowmeters are usable, but the uncertainty of measurement process is higher (Baker, 2000). Actually, both models presented a slight difference on uncertainty limits. The favorable aspect of the chosen logarithmic model was related to the Method of Least Squares, which was also developed in the embedded software. The mathematical procedures to determine the fitting model coefficients of the logarithmic model are easier than the theoretical model.

A differential manometer was used to acquire differential pressure data in order to determine the coefficient of local head loss $(K)$ of the EDFF. From average data the local head loss $\left(h f_{\text {loc }}\right)$, flow velocity $(V)$, Reynolds number $(R e)$, and the coefficient of local head loss $(K)$ were calculated (Table 7). The $\mathrm{K}$ coefficient was almost constant in a value closer to 0.55 considering Reynolds numbers larger than $10^{5}$ (Figure 8 ). This constant $K$ for high values of Reynolds numbers is mentioned by Porto (1998) and Azevedo Netto (1998). In a comparison of values, a Venturi flowmeter generally presents $K$ of 2.5 (Neves, 1974).

\section{Conclusion}

The low-cost Electronic Drag Force Flowmeter (EDFF) developed in this research provides an easy and accurate way of measuring flow. The embedded software and the data acquisition system ensure to set some interactive routines like calibration, parameters adjustment, and also instantaneous flowmeter measurement without the use of a computer. The EDFF presents satisfactory performance parameters for its category. The adopted logarithmic model results in performance parameters similar to the theoretical model, for the evaluated flowmeter evaluation range. An innovative electronic flowmeter was developed with potential for agricultural applications.

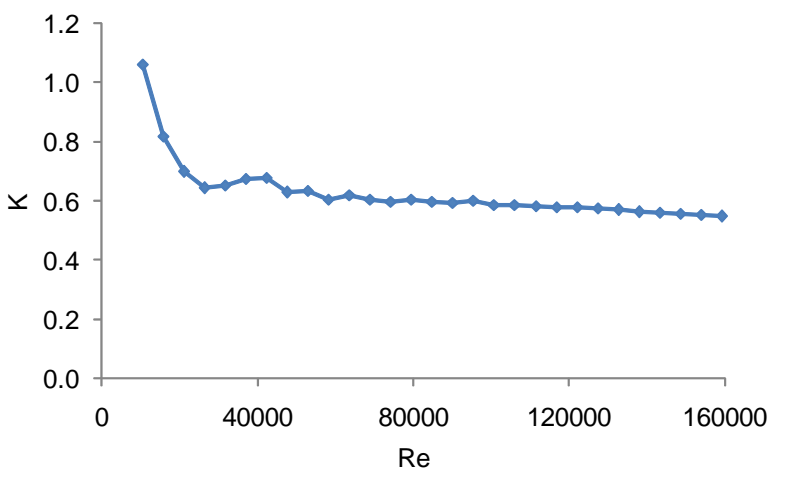

Figure 8 - Local head loss coefficient $(K)$ Vs. Reynolds number $(R e)$ for the developed Eletronic Drag Force Flowmeter.

\section{Acknowledgement}

To the following Brazilian Institutions for their financial support: Ministry of Science and Technology (MCT), National Scientific and Technological Development Council (CNPq), São Paulo State Scientific Foundation (FAPESP), and National Institute of Science and Technology in Irrigation Engineering (INCTEI).

\section{References}

Azevedo Netto, J.M.; Fernandez, M.F.; Araújo, R.; Ito, A.E. 1998. Handbook of Hydraulics. 8ed. Edgard Blücher, São Paulo, SP, Brazil. (in Portuguese).

Baker, R.C. 2000. Flow Measurement Handbook: Industrial Designs, Operating Principles, Performance, And Applications. Cambridge University Press, New York, NY, USA.

Cacuci, D.G. 2003. Sensitivity and Uncertainty Analysis: Theory. v.1. Chapman \& Hall, New York, NY, USA.

Cascetta, F. 1995. Short history of the flowmetering. ISA Transactions 34: 229-243.

Dattalo, P. 2008. Determining Sample Size: Balancing Power, Precision and Practicality. Oxford University Press, New York, NY, USA.

Delmée, G.J. 2003. Flow Measurement Handbook. 3ed. Edgard Blücher, São Paulo, SP, Brazil. (in Portuguese).

Drosg, M. 2007. Dealing with Uncertainties: A Guide To Error Analysis. Springer, Berlin, Germany.

Furness, R.A. 1991. BS 7405: The principles of flowmeter selection. Flow Measurement and Instrumentation 2: 233-242. 
Table 7 - Used data to estimate the coefficient of local head loss for the developed Electronic Drag Force Flowmeter (EDFF).

\begin{tabular}{|c|c|c|c|c|c|}
\hline$Q$ & $\Delta b$ & $b f_{l o c}$ & $V$ & $R e$ & $K$ \\
\hline $\mathrm{dm}^{3} \mathrm{~s}^{-1}$ & $\mathrm{~mm}$ & $\mathrm{~m}$ & $\mathrm{~m} \mathrm{~s}^{-1}$ & - & - \\
\hline 0.00 & - & - & - & - & - \\
\hline 0.28 & - & - & 0.0812 & 5305.7 & - \\
\hline 0.56 & 1.9 & 0.0014 & 0.1624 & 10611.4 & 1.0603 \\
\hline 0.83 & 3.3 & 0.0025 & 0.2436 & 15917.1 & 0.8185 \\
\hline 1.11 & 5.0 & 0.0038 & 0.3248 & 21222.8 & 0.6975 \\
\hline 1.39 & 7.2 & 0.0054 & 0.4060 & 26528.5 & 0.6429 \\
\hline 1.67 & 10.5 & 0.0079 & 0.4872 & 31834.2 & 0.6510 \\
\hline 1.94 & 14.8 & 0.0111 & 0.5684 & 37139.9 & 0.6742 \\
\hline 2.22 & 19.4 & 0.0146 & 0.6495 & 42445.6 & 0.6766 \\
\hline 2.50 & 22.8 & 0.0171 & 0.7307 & 47751.3 & 0.6283 \\
\hline 2.78 & 28.4 & 0.0213 & 0.8119 & 53057.0 & 0.6339 \\
\hline 3.06 & 32.8 & 0.0246 & 0.8931 & 58362.6 & 0.6051 \\
\hline 3.33 & 40.0 & 0.0300 & 0.9743 & 63668.3 & 0.6200 \\
\hline 3.61 & 45.7 & 0.0343 & 1.0555 & 68974.0 & 0.6036 \\
\hline 3.89 & 52.4 & 0.0393 & 1.1367 & 74279.7 & 0.5968 \\
\hline 4.17 & 60.8 & 0.0456 & 1.2179 & 79585.4 & 0.6032 \\
\hline 4.44 & 68.4 & 0.0513 & 1.2991 & 84891.1 & 0.5964 \\
\hline 4.72 & 76.8 & 0.0576 & 1.3803 & 90196.8 & 0.5932 \\
\hline 5,00 & 87.0 & 0.0653 & 1.4615 & 95502.5 & 0.5994 \\
\hline 5.28 & 94.6 & 0.0710 & 1.5427 & 100808.2 & 0.5849 \\
\hline 5.56 & 105.0 & 0.0788 & 1.6239 & 106113.9 & 0.5859 \\
\hline 5.83 & 115.0 & 0.0863 & 1.7051 & 111419.6 & 0.5821 \\
\hline 6.11 & 125.4 & 0.0941 & 1.7863 & 116725.3 & 0.5783 \\
\hline 6.39 & 136.8 & 0.1026 & 1.8674 & 122031.0 & 0.5772 \\
\hline 6.67 & 148.4 & 0.1113 & 1.9486 & 127336.7 & 0.5751 \\
\hline 6.94 & 159.4 & 0.1196 & 2.0298 & 132642.4 & 0.5693 \\
\hline 7.22 & 170.2 & 0.1277 & 2.1110 & 137948.1 & 0.5620 \\
\hline 7.50 & 182.8 & 0.1371 & 2.1922 & 143253.8 & 0.5597 \\
\hline 7.78 & 195.4 & 0.1466 & 2.2734 & 148559.5 & 0.5563 \\
\hline 8.06 & 207.8 & 0.1559 & 2.3546 & 153865.2 & 0.5515 \\
\hline 8.33 & 220.4 & 0.1653 & 2.4358 & 159170.9 & 0.5466 \\
\hline
\end{tabular}

Greene, A.K. 1993. Target flowmeter used in dairy processing plant. International Dairy Journal 3: 663-667.

International Organization for Standardization [ISO]. 1985. ISO 5168: Fluid Flow Measurement Uncertainty (draft). ISO, Geneva, Switzerland.

Merzkirch, W. 2005. Fluid Mechanics of Flow Metering. Springer, Berlin, Germany.

Munson, B.R.; Young, D.F.; Okiishi, T.H. 2004. Fundamentals of Fluid Mechanics. 4ed. Edgard Blücher, São Paulo, SP, Brazil. (in Portuguese).

Neves, E.T. 1973. Course of Hydraulics. 2ed. Editora Globo, Porto Alegre, RS, Brazil. (in Portuguese).

Porto, R.M. 1998. Hydraulic Fundamentals. 4ed. EESC-USP, São Carlos, SP, Brazil. (in Portuguese).

Rabinovich, S.G. 2005. Measurement Errors And Uncertainties: Theory and Practice. 3ed. Springer, New York, NY, USA.
Souza, M.J.F. 2009. Model fitting by using Method of Least Squares. Available at: http://www.decom.ufop.br/prof/marcone/ Disciplinas / Metodos Numericose Estatisticos/ QuadradosMinimos.pdf. [Accessed Jun. 20, 2009]. (in Portuguese).

Upp, E.L.; La Nasa, P.J. 2002. Fluid Flow Measurement: A Practical Guide To Accurate Flow Measurement. 2ed. Gulf Professional, Woburn, MA, USA.

Zhao, Y.; Chen, K.; Yang, J. 2005. Novel target type flowmeter based on differential fiber Bragg grating sensor. Measurement 38: 230235.

Received December 03, 2009

Accepted November 16, 2010 